\title{
Rancangan Laboratorum Virtual untuk Pembelajaran Fisika SMA
}

\author{
Masril $^{1}$, Hidayati $^{1}$, Yenni Darvina ${ }^{1}$ \\ ${ }^{1)}$ Jurusan Fisika FMIPA Universitas Negeri Padang \\ masrilqch@yahoo.com: hidayatiunp@yahoo.co.id
}

\begin{abstract}
One of the problems found in the implementation of the curriculum of 2013 is not all competency skills can be performed well. Therefore, to overcome these problems, virtual laboratory designed to competencies skill of physics. One of the design objectives virtual laboratory is to improve the quality of education and learning in physics in high school. The method used in this study is a research method development four D model with the definition phase, design phase, development phase, and dissemination phase. Research has reached the stage of development and has been tested valid specialist. The instrument used in the research is a questionnaire consisting of: 1) the material substance; 2) The display of visual communication; 3) instructional design; 4) the use of software; and 5) Linguistic. The results obtained to test the validity in general has been very good category (85.6), so that the design of virtual labs designed can already be used in high school.
\end{abstract}

Keywords : Curriculum 2013, the virtual laboratotory, the quality of education

This is an open access article distributed under the Creative Commons 4.0 Attribution License, which permits unrestricted use, distribution, and reproduction in any medium, provided the original work is properly cited $\odot 2018$ by author and Universitas Negeri Padang.

\section{PENDAHULUAN}

Salah satu penyebab rendahnya prestasi siswa dalam pembelajaran adalah terbatasnya sarana laboratorium pada sekolah menengah di Indonesia, padahal kegiatan laboratorium merupakan suatu keharusan untuk membangun pembelajaran bermakna pada diri siswa. Keterampilan proses adalah salah satu metode pengajaran yang bermakna bagi siswa karena metoda ini menekankan bagaimana bahan pelajaran itu diajarkan dan dipelajari. Dalam belajar keterampilan proses, peserta didik harus aktif. Belajar keterampilan tidak dapat dipisah kan dengan belajar konsep. Keduanya merupa kan garis kontinu. Belajar konsep menekankan pada penghayatan konsep sedangkan keteram pilan proses menekankan pada perolehan dan pemahaman fakta dan prinsip (Soegeng, 2000). Belajar keterampilan proses tidak mungkin terjadi jika tidak ada materi atau bahan yang dipelajari. Sebaliknya, belajar konsep tidak akan terjadi jika tidak ada keterampilan proses pada tiap peserta didik yang belajar (Soegeng, 2000). Laboratorium sebagai tempat pelaksanaan ketrampilan proses perlu ditingkatkan fungsinya karena dalam laborato rium tempat untuk menguji, meneliti dan membuktikan teori yang ada. Hasil penelitian tentang pendekatan keterampilan proses sains dengan metode eksperimen berpengaruh terhadap prestasi belajar IPA (Rina Astuti, 2012) Sebagai suatu lembaga pendidikan, seharusnya sekolah sudah menyiapkan laboratorium yang memadai untuk kegiatan kete rampilan bagi siswa. Namun fakta menunjukkan bahwa berdasarkan hasil observasi yang penulis lakukan di sekolah-sekolah Menengah Tingkat Atas (SMA) di Kota Padang diperoleh hasil bahwa sebagian besar sekolah tidak punya fasilitas praktikum yang lengkap untuk menunjang pelaksanaan kurikulum 2013 sehingga banyak materi yang harus dipraktikumkan tidak dilakukan kegiatan praktikum, akibatnya banyak konsep pembe lajaran yang terabaikan. Berdasarkan pengalaman peneliti dalam penelitian hibah bersaing tahun 2015, ditemukan beberapa kelemahan pembelajaran di sekolah, diantaranya ketika Lembar Kerja Siswa (LKS) untuk praktikum sudah dirancang sesuai dengan tuntutan kurikulum, ternyata praktikum tidak bisa dilaksanakan karena tidak adanya sarana praktikum yang tersedia. 
Secara teoritis, proses pembelajaran di kelas maupun di laboratorium mencakup dalam mengembangkan tiga ranah yaitu kognitif, akfektif dan psikomotor. Untuk mencapai tiga ranah tersebut dibutuhkan keseimbangan antara penyampaian teori dan kegiatan praktikum. Terutama dalam materi tertentu, praktikum sangat dibutuhkan. Hal tersebut dapat terjadi karena kegiatan di kelas hanya dapat menilai ranah kognitif sedangkan pelaksanaan praktikum dapat mencakup penilain dalam ranah afektif dan psikomotorik siswa. Kegiatan di dalam kelas dan di laboratorium dalam proses pembelajarn merupakan hal yang tidak dapat dipisahkan karena saling berkaitan antara satu dengan yang lain untuk mencapai tujuan dalam pembelajaran tersebut. Disamping itu sebagian besar konsep fisika bersifat abstrak sehingga sulit untuk dipahami secara langsung.

Oleh sebab itu, untuk mengatasi kendala dalam kegiatan praktikum dapat dilakukan dengan berbagai cara, diantaranya adalah dengan pemanfaatan Teknologi Informasi dan Komunikasi (TIK), yang ditunjang dengan penggunaan komputer sebagai perangkat TIK, misalnya eksperimen semu (virtual lab). Meskipun virtual lab bukan kegiatan yang sesungguhnya, tetapi siswa dapat melakukan praktikum seperti praktikum sesungguhnya. Virtual laboratory (virtual lab) merupakan salah satu proses pembelajaran berbasis TIK yang dapat dijadikan sebagai solusi alternatif pembelajaran dengan metode praktikum. Praktikum dengan menggunakan komputer disebut dengan virtual laboratory. Virtual laboratory adalah serangkaian alat-alat labo ratorium yang berbentuk perangkat lunak (software) komputer berbasis multimedia interaktif, yang dioperasikan dengan komputer dan dapat mensimulasikan kegiatan di laboratorium seakan-akan pengguna berada pada laboratorium sebenarnya (Imron, 2012). Sedangkan menurut (Budhu, 2002) virtual laboratory objek multimedia interaktif yang kompleks dan termasuk bentuk digital baru, dengan tujuan pembelajaran implisit atau eksplisit.

Metode praktikum di laboratorium riil merupakan suatu bentuk pengajaran yang bersifat khusus dan istimewa yang dimanfaatkan seoptimal mungkin yang bertujuan agar siswa mendapat kesempatan untuk menguji dan melaksanakan dalam keadaan yang nyata apa yang diperoleh dalam teori. Dalam metode ini siswa dapat aktif melakukan percobaan secara langsung, mengamati prosesnya dan menyim pulkan hasil percobaannya, sehingga siswa dapat membentuk konsep dari teori yang dipelajarinya.

Dalam melaksanakan praktikum tidak hanya melakukan eksperimen di dalam labora torium, siswa juga dapat melakukannya pada laboratorium virtual. Karakteristik labora torium virtual adalah program yang berisi alat-alat laboratorium yang berfungsi sebagaimana alat riil. Para siswa diajak untuk memberikan respon yang ada pada laboratorium virtual, kemudian komputer akan merespon dan memberikan umpan balik segera pada siswa dalam bentuk programmed instruction (Slavin, 2008).

Adanya virtual laboratory kesulitan peserta didik dalam memahami konsep fisika dan kesulitan guru dalam merancang praktikum fisika dapat diatasi. Virtual laboratory juga meminimal kan biaya dalam pengadaan alat dan bahan praktikum. Penjelasan lebih detail tentang manfaat virtual laboratory diberikan oleh (Farreira, 2010) sebagai berikut : 1) Mengurangi keterbatasan waktu, jika tidak ada cukup waktu untuk mengajari seluruh peserta didik di dalam laboratorium hingga mereka paham; 2) Mengurangi hambatan geografis, jika terdapat peserta didik yang lokasi tempat tinggalnya jauh dari sekolah; 3) Ekonomis, tidak membutuhkan bangunan laboratorium, alat-alat dan bahanbahan seperti pada laboratorium konvensional; 4) Meningkatkan kualitas eksperimen, karena memungkinkan untuk diulang untuk memper jelas keraguan dalam pengukuran di labora torium; 5) Meningkatkan efektivitas pembe lajaran, karena peserta didik akan semakin lama menghabiskan waktunya untuk praktikum secara berulang-ulang; 6) Meningkatkan keamanan dan keselamatan, karena tidak berinteraksi dengan alat dan bahan yang nyata.

Sedangkan kelemahan dalam peman faatan virtual laboratory adalah: 1) Peserta didik harus terkoneksi internet atau menggunakan komputer untuk menjalankan simulasi suatu praktikum; 2) Kurangnya pengalaman di 
laboratorium nyata, sehingga terjadi ke bingungan peserta didik dalam merangkai dan mengoperasikan alat di virtual laboratory; dan 3) Virtual laboratory tidak memberikan pengalaman praktikum secara nyata.

Melalui pembelajaran praktikum dengan memanfaatkan virtual laboratory diharapkan proses pembelajaran fisika menjadi lebih menarik dan interaktif sehingga berakibat pada peningkatan proses berpikir dan hasil belajar fisika peserta didik. Dengan demikian, perkem bangan teknologi informasi membantu upaya pembangunan kemajuan dunia pendidikan. Adanya virtual laboratory kesulitan peserta didik dalam memahami konsep fisika dan kesulitan guru dalam merancang praktikum fisika dapat diatasi.

Pada saat ini Virtual laboratory sudah banyak dikembangkan. Salah satu contoh yang sudah banyak digunakan adalah virtual laboratory yang dikembangkan oleh University of Colorado, yaitu Physics Education Techno logy $(\mathrm{PhET})$. Di dalam PhET terdapat simulasi yang bersifat teori dan percobaan yang melibatkan pengguna secara aktif. Pengguna dapat memanipulasi kegiatan-kegiatan yang berkaitan dengan eksperimen, sehingga selain dapat membangun konsep, PhET juga dapat digunakan untuk memunculkan keterampilan proses sains. Kuntungan yang ditawarkan oleh simulasi PhET, yaitu dapat di akses di unduh secara bebas dan tanpa berbayar (freeware) pada situs http://PhET.colorado.edu., serta dapat digunakan tanpa terkoneksi dengan internet (offline). Selain itu, baru-baru ini PhET telah diterjemahkan dalam versi bahasa Indonesia. Dengan adanya program PhET ini memung kinkan dapat digunakan untuk praktikum mata pelajaran fisika di SMA yang dilengkapi dengan LKS dari setiap judul yang dipraktikumkan sesuai dengan KD yang ada sehingga semua konsep yang ada dalam kurikulum bisa diajarkan. Memang sudah banyak penelitianpenelitian lain yang telah melakukan penelitian tentang penggunaan simulasi PhET dalam pem belajaran, namun penelitian yang dilakukan hanya sebatas bagian-bagian sub materi yang terbatas. Hasil penelitian yang diperoleh dari penelitian yang terdahulu dapat disimpulkan bahwa penggunaan simulasi PhET dapat membangun konsep dan keterampilan proses sains siswa.

Dalam menerapkan pendekatan proses, maka laboratrium merupakan salah satu untuk proses penemuan sains melalui serangkian aktivitas. Penemuan-penemuan sains dilakukan melalui aktivitas eksperimen di laboratorium. Fisika merupakan cabang ilmu pengetahuan yang mempelajari perilaku dari fenomena/gejala yang ada di alam dalam lingkup ruang dan waktu (Masril, 2018). Dalam mengungkap fenomena/gejala alam diperlukan rangkaian proses penelitian seperti pengamatan dan pengukuran. Oleh sebab itu ilmu fisika juga disebut sebagai ilmu eksperimental. Eksperimen atau praktikum adalah kegiatan untuk menga mati, menguji dan membuktikan teori sehingga didapatkan pengembangan teori secara ilmiah.

Sebagai ilmu eksperimental kedudukan praktikum dalam pembelajaran fisika menjadi sangat penting. Salah satu alasan adalah karena sebagian besar konsep fisika bersifat abstrak sehingga sulit untuk dipahami secara langsung. Adanya praktikum memungkin kan pemahaman konsep menjadi lebih mudah dan peserta didik dapat belajar untuk melakukan penyelidikan dan mengumpulkan bukti-bukti dari berbagai sumber, mengem bangkan penjelasan dari data, dan berkomu nikasi serta mempertahankan kesimpulan (NSTA, 2004).

Pelaksanaan praktikum juga terkait dengan tujuan pembelajaran fisika sebagai proses, yaitu meningkatkan keterampilan berpikir peserta didik sehingga mereka tidak hanya mampu dan terampil dalam bidang psikomotorik, melainkan juga mampu berpikir sistematis, objektif, dan kreatif (Gunawan, 2012). Sesuai dengan tuntutan kurikulum 2013, yang menetapkan salah satu kompetensi inti adalah kelompok keterampilan. Kompetensi ini menekankan pada proses pembelajaran ilmiah yang berguna bagi pembentukan keterampilan peserta didik.

Kegiatan praktikum fisika di tingkat SMA diarahkan pada suatu pembuktian, pemahaman, dan penerapan dari konsep, hukum atau teori fisika yang dipelajari. Namun demikian tidak semua percobaan dapat dilakukan secara langsung di laboratorium, karena topik-topik itu 
banyak yang abstrak, seperti dalam fisika modern, energy, dan lain sebagainya. Selain mahalnya peralatan praktikum, rancangan praktikum langsung juga sulit dilakukan karena konsepnya yang abstrak. Padahal konsep fisika yang abstrak perlu memanfaatkan kegiatan praktikum untuk mempermudah peserta didik dalam memahami konsep tersebut.

Alternatif solusi yang mulai dikem bangkan untuk mengatasi permasalahan di atas adalah memanfaatkan komputer sebagai media informasi dalam kegiatan pembelajaran. Termasuk juga dalam kegiatan praktikum. Komputer dapat digunakan untuk memodifikasi praktikum dan menampilkan praktikum lengkap dalam bentuk virtual, terutama untuk konsep fisika yang abstrak (Gunawan, 2012). Oleh sebab itu tujuan penelitian ini adalah untuk menentukan nilai validitas LKS virtual yang dirancang.

\section{METODE PENELITIAN}

\section{Jenis Penelitian}

Penelitian yang dilakukan adalah penelitian pengembangan (Research and Development $(R \& D)$ ) karena penelitian pengembangan terdiri dari 3 komponen besar yaitu adanya model pengembangan, prosedur pengembangan,, dan uji coba produk. Model R \& D yang digunakan dalam pengembangan laboratorium virtual adalah model 4-D (four $D$ model) yang terdiri dari tahap : pendefinisian (define), perancangan (design), pengembangan (development), dan penyebaran (dessiminate) (Thiagarajan, 1974). Dalam tulisan ini laporkankan hasil penelitian sampai pada langkah ketiga yaitu pengembangan.

\section{Objek Penelitian}

Sebagai objek dalam penelitian yang dilakukan adalah perangkat laboratorium virtual yang disusun dalam bentuk Lembar kerja siswa (LKS). Untuk menguji kelayakan LKS yang dikembangkan maka dilakukan validasi kepada para ahli di bidang masing-masing sebanyak lima orang. Uji validitas yang dilakukan sebatas uji validitas konten.

\section{Teknik Pengumpulan dan Analisis Data}

Teknik pegumpulan data yang digunakan dalam penelitian adalah melalui angket, dan teknik analisisnya menggunakan statistic deskriptif melalui hasil angket yang diperoleh.
Angket yang dirancang terdiri dari lima indikator yaitu kelayakan isi, penggunaan bahasa, penyajian, kegrafisan, dan produk laboratorium virtual yang dikembangkan. Data yang diperoleh dideskripsikan melalui grafik.

\section{HASIL DAN PEMBAHASAN}

\section{Hasil Penelitian}

a. Hasil Validasi Indikator Kelayakan Isi

Hasil validasi laboratorium virtual untuk indikator kelayakan isi diperoleh dari nilai setiap pernyataan dari indikator yang terdiri dari 8 pernyataan yaitu : 1) kesesuaian materi dengan KI dan $\mathrm{KD}$; 2) Kesesuaian dengan kebutuhan siswa; 3) kesesuaian dengan kebutuhan laboratorium virtual; 4) kebenaran substansi materi; 5) kese suaian materi dengan kehidupan sehari-hari; 6) manfaat untuk penambahan wawasan penge tahuan; 7) kesesuaian latihan dan evaluasi dengan materi; 8) kesesuaian dengan nilai-nilai, moralitas, sosial. Hasil yang diperoleh dari setiap pernyataan indikator kelayakan di diplot pada Gambar 1:

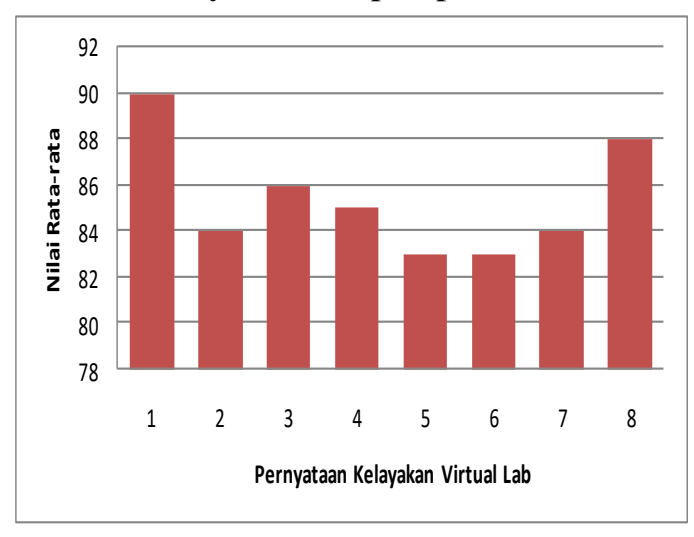

Gambar 1. Hasil Validasi Kelayakan Virtual Lab

Berdasarkan nilai rata-rata setiap indikator pada komponen kelayakan Virtual Lab, nilai kedelapan indikator berkisar antara nilai 82 sampai 90, dimana nilai maksimum setiap indikator adalah 100. Dari kedelapan indikator dapat ditentukan nilai validasi untuk komponen kelayakan Virtual lab yaitu 85,38. Dengan demikian, komponen kelayakan Virtual lab berada pada kategori sangat valid.

b. Hasil Validasi Indikator Penggunaan Bahasa

Hasil validasi virtual lab untuk indikator penggunaan bahasa diperoleh dari nilai setiap pernyataan dari indikator yang terdiri dari 12 pernyataan yaitu 1) keterbacaan, 2) kepadatan ide, 
3) keindahan gaya bahasa, 4) penggunaan panjang pendeknya kalimat, 5) cara membangun kalimat, 6) cara membangun paragraf, 7) penggunaan tanda baca, 8) cara penulisan istilah-istilah fisika, 9) cara penulisan persamaan fisika, 10) cara penulisan judul tabel dan gambar, 11) kejelasan informasi, dan 12) penggunaan bahasa secara efektif dan efisien. Hasil yang diperoleh dari setiap pernyataan indikator penggunaan bahasa di diplot pada Gambar 2:

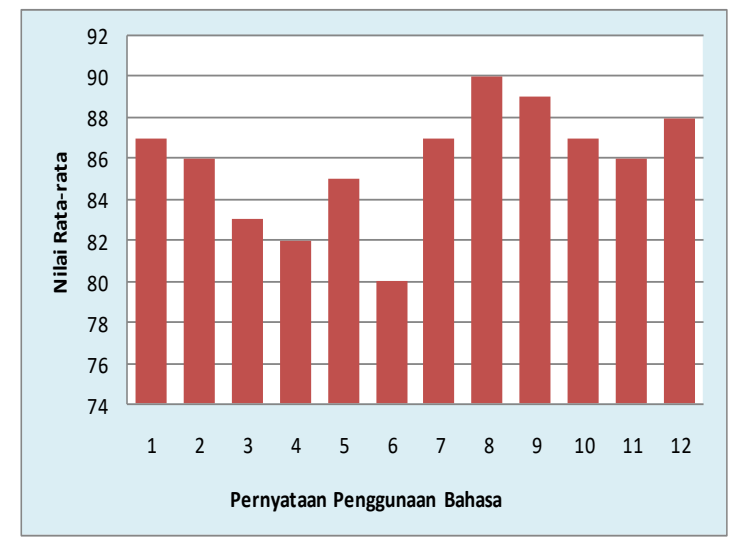

Gambar 2. Hasil Validasi Penggunaan Bahasa

Berdasarkan nilai rata-rata indikator pada komponen kelayakan pernyataan penggunaan bahasa, nilai keduabelas indikator berkisar antara nilai 80 sampai 90. Dari duabelas indikator dapat ditentukan nilai validasi untuk komponen kela yakan penggunaan bahasa yaitu 85,83 . Berarti komponen kelayakan penggunaan bahasa berada pada kategori sangat valid.

c. Hasil Validasi Indikator Penyajian Labora torium Virtual

Hasil validasi Laboratorium Virtual untuk indikator penyajian diperoleh dari nilai setiap pernyataan dari indikator yang terdiri dari 5 pernyataan yaitu : 1) kejelasan tujuan; 2) urutan penyajian; 3) pemberian motivasi; 4) interaktivitas (stimulus dan respond); dan 5) kelengkapan informasi. Hasil yang diperoleh dari setiap pernyataan indikator penyajian Laboratorium Virtual di diplot pada Gambar 3.

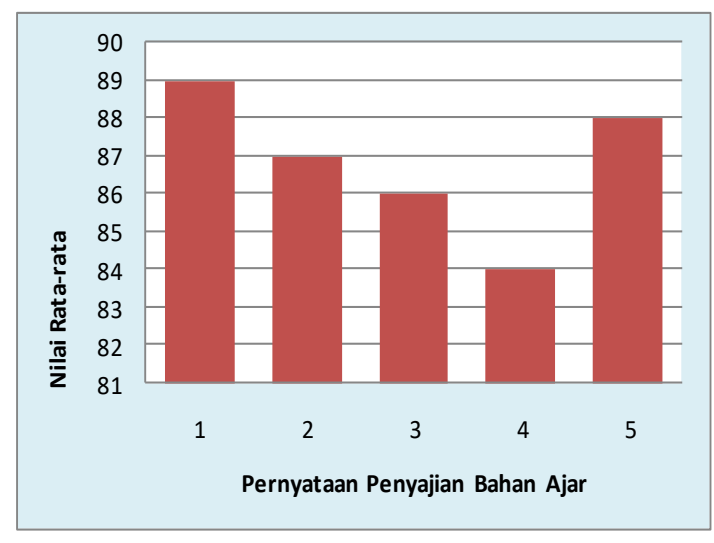

Gambar 3. Hasil Validasi Penyajian

Pada Gambar 3 dapat dilihat nilai rata-rata indikator pada komponen Penyajian Bahan ajar. Nilai kelima indikator berkisar antara nilai 84 sampai 89. Dari lima indikator dapat ditentukan nilai validasi untuk komponen Penyajian Bahan Ajar yaitu 86,8. Dengan demikian, komponen kelayakan kelayakan pernyataan penggunaan bahasa berada pada kategori sangat valid.

d. Hasil Validasi Indikator Kegrafisan Labora torium Virtual

Hasil validasi Laboratorium Virtual untuk indikator kegrafisan diperoleh dari nilai setiap pernyataan dari indikator yang terdiri dari 5 pernyataan yaitu : 1) penggunaan font (jenis dan ukuran); 2) lay out, tata letak; 3) ilustrasi, grafis, gambar, foto; dan 4) desain tampilan. Hasil yang diperoleh dari setiap pernyataan indikator kegrafisan Laboratorium Virtual di diplot pada Gambar 4.

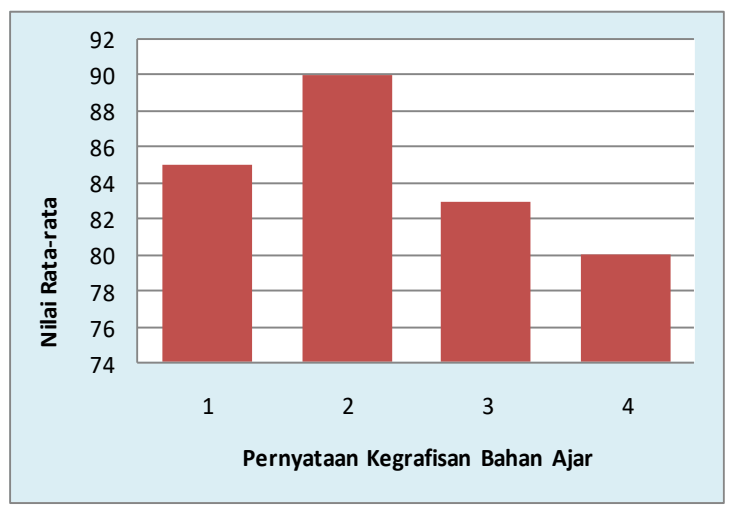

Gambar 4. Hasil Validasi Kegrafisan Laboratorium Virtual 
Pada Gambar 4 dapat dilihat nilai rata-rata setiap indikator pada komponen Kegrafisan Laboratorium Virtual. Nilai keempat indikator berkisar antara nilai 80 sampai 90. Dari lima indikator dapat ditentukan nilai validasi untuk komponen Penyajian Bahan Ajar yaitu 84,5. Dengan demikian, komponen Kegrafisan Laboratorium Virtual berada pada kategori valid.

e. Hasil Validasi Indikator Langkah-langkah Laboratorium Virtual yang Dikembangkan

Hasil validasi Laboratorium Virtual untuk indikator Laboratorium Virtual yang dikem bangkan diperoleh dari nilai setiap pernyataan dari indikator yang terdiri dari 8 pernyataan yaitu : 1) rancangan; 2) keterkaitan dengan konsep; 3) kemudahan akses; 4) interaktif; 5) penuntun yang dikembangkan; 6) kedalaman materi; 7) meme nuhi semua KD; 8) evaluasi dalam bentuk quiz memadai. Hasil yang diperoleh dari setiap pernyataan indikator Laboratorium Virtual yang dikembangkan di diplot pada Gambar 5.

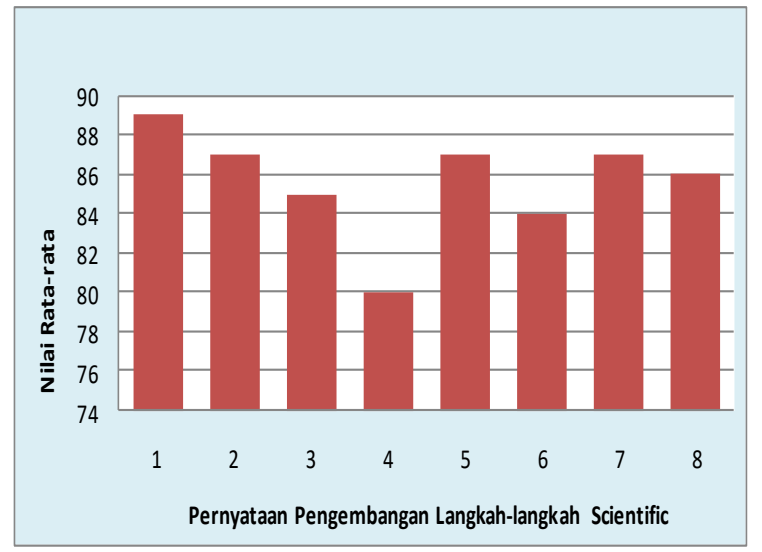

Gambar 5. Hasil Validasi Pengembangan Virtual Laboratorium

Gambar 5 dapat dilihat nilai rata-rata setiap indikator pada komponen Pengembangan Virtual Laboratorium. Nilai kedelapan indikator berkisar antara nilai 80 sampai 89. Dari delapan indikator dapat ditentukan nilai validasi untuk komponen Pengembangan Virtual Laboratorium yaitu 85,63. Dengan demikian, komponen Pengembangan Virtual Laboratorium berada pada kategori sangat valid.

\section{Pembahasan}

Berdasarkan hasil yang diperoleh dari setiap indikator virtual lab dapat dijelaskan sebagai berikut: Nilai indikator untuk kelayakan isi secara umum sudah nilai yang baik karena virtual lab yang dirancang sudah menunjukkan kesesuaian materi dengan kompetensi dasar yang ada dan menunjukkan adanya kesesuaian dengan kebutuhan siswa, artinya kompetensi dasar yang dituntut oleh kurikulum sudah bisa tercapai dengan baik. Ditinjau dari segi manfaat virtual lab yang dikembangkan sangat bermanfaat dalam meme nuhi kebutuhan praktikum untuk seluruh kompetensi dasar yang ada sehingga tidak ada lagi KD yang tidak bisa dipraktikumkan. Dalam pengembangan lembar kerja siswa, setiap materi diuraikan sesuai dengan tuntutan praktikum yang ada sehingga memudahkan siswa untuk membuktikan konsep-konsep yang ada dalam materi. Di samping itu langkah-langkah untuk mempelajari virtual lab dibuat serinci mungkin sehingga memudahkan siswa untuk menggunakan virtual lab yang dikembangkan.

Nilai indikator untuk penggunaan bahasa secara umum sudah menunjukkan nilai validitas tinggi. Hal ini disebabkan kepadatan ide dalam mengembangkan kalimat, cara membangun kalimat, cara membangun paragraf, cara penulisan judul tabel dan gambar, dan penggunaan bahasa secara efektif dan efisien sudah sesuai dengan ejaan yang disempurnakan. Disamping itu tingginya nilai validitas ini disebabkan dalam pengembangan virtual laboratorium banyak mengungkapkan ide-ide yang baru yang memudahkan siswa untuk mempelajari virtual laboratorium yang dikembangkan.

Nilai indikator untuk penggunaan pengembangan virtual laboratorium sudah menunjukkan nilai validitas tinggi karena virtual lab pemberikan motivasi dan interaktivitas (stimulus dan respond). Secara teoritis, pemberian motivasi dapat meningkatkan keaktifan anak sehingga prestasinya juga dapat meningkat. Di samping itu penyajian virtual laboratorium yang dilengkapi dengan animasi yang menarik bagi siswa juga dapat meningkatkan minat siswa untuk mempelajarinya sehingga siswa tertarik untuk mempelajarinya. Penyajian virtual laboratorium melalui ICT memudahkan siswa untuk belajar dimana saja dan kapan saja.

Nilai indikator untuk kegrafisan virtual lab sudah menunjukkan nilai validitas tinggi, hal ini disebabkan oleh penggunaan font yang bervariasi, 
lay out dan tata letak yang tersusun rapi, ilustrasi gambar yang menarik dan desain tampilan sudah baik. Disamping itu ilusrasi gambar diberi warna yang menarik dan dilengkapi dengan keterangan yang lengkap.

Hasil validasi Laboratorium Virtual untuk indikator Laboratorium Virtual yang dikem bangkan sudah berkategori tinggi karena nilai setiap pernyataan dari indikator yang dikembangkan sudah tinggi seperti : rancangan, Keterkaitan dengan konsep, Kemudahan akses, Interaktif, penuntun yang mudah dipahami, kedalaman materi, dan Evaluasi dalam bentuk quiz yang interaktif.

Berdasarkan hasil validasi dan saran-saran yang diberikan oleh validator perlu dilakukan revisi terhadap desain produk yang dihasilkan. Revisi yang dilakukan terutama menyangkut kedalaman materi, format tulisan, tampilan, dan yang lebih penting lagi adalah langkah-langkah penggunaan virtual lab. Secara umum dapat dikatakan bahwa produk virtual lab berbasis ICT telah memiliki deskripsi yang baik sebagai salah satu virtual lab fisika karena telah sesuai dengan konsep rancangan sebuah virtual lab, berdasarkan teori dan penelitian yang ada sebelumnya. Produk virtual lab ini dapat digunakan untuk pembelajaran kurikulum 2013 tingkat sekolah menengah atas SMA/MA.

\section{Kesimpulan}

\section{KESIMPULAN}

Berdasarkan hasil analisis data yang dilakukan maka dapat di simpulkan bahwa hasil uji validitas virtual lab termasuk kategori tinggi dan Virtual lab yang dirancang ini sudah dapat digunakan untuk pembelajaran fisika kurikulum 2013 di SMA.

\section{Saran}

Dalam rangka persiapan menuju kurikulum nasional diberlakukan, diharapkan virtual lab dikembangkan untuk mata pelajaran lain di SMP dan SMA seperti IPA SMP.

DAFTAR PUSTAKA

Budhu, M. (2002). Virtual Laboratories for Engineering Education. Paper Presented at International Conference on Engineering Education (pp. 18-21). Manchester: U.K.

Farreira, M. (2010). Intelligent Classroom and Smart Software : Teaching and Learning in today's University. Springer Publication.

Gunawan, L. (2012). Model Virtual Laboratory Fisika Modern untuk Meningkatkan Disposisi Kritis Calon Guru . Jakarta: Cakrawala .

Imron, M. (2012). Memanfaatkan Laboratorium Virtual.

http://www.mazguru.wordpress.com/20 12/04/19/oyo-manfaatkan-laboratoriumvirtual.

Masril, Hidayati, Yenni D, (2018). The Development of Virtual Laboratory Using ICT for Physics in Senior High School. IOP Conference Series: Materials Science and Engineering, Volume 335, conference 1. IOP Publishing Ltd.

NSTA, N. S. (2004). Position statement on scientific inquiry. online,http:// www.nsta. org/ about/ positions/ inquiry.aspx.

Rina Astuti, W. S. (2012). Pembelajaran IPA dengan Pendekatan Keterampilan Proses Sains Menggunakan Metode Eksperimen Bebas Termodifikasi dan Eksperimen Terbimbing Ditinjau dari Sikap Ilmiah dan Motivasi Belajar Siswa. JURNAL INKUIRI ISSN: 22527893, Vol 1, No 1, http://jurnal.pasca.uns.ac.id, 51-59.

Slavin, R. (2008). Cooperative Learning Theory Research and Practice. Bandung (Terj.Nurulita Yusron): Nusa Media.

Soegeng, S. (2000). Problematika Pendidikan dan Cara Pemecahannya. Jakarta: Kreasi Pena Gading.

Thiagarajan, S. S. (1974). Instructional Development for Training Teachers of Expectional Children. Minneapolis, Minnesota: Leader ship Training Institute/ Special Education, University of Minnesota. 